\title{
Formation and evolution of yardangs activated by Late Pleistocene tectonic movement in Dunhuang, Gansu Province of China
}

\author{
Yanjie Wang ${ }^{1,2}$, Fadong Wu ${ }^{1, *}$, Xujiao Zhang ${ }^{1}$, Peng Zeng ${ }^{1}$, \\ Pengfei MA ${ }^{1}$, Yuping Song ${ }^{1}$ and HaO $\mathrm{CHU}^{1}$ \\ ${ }^{1}$ School of Earth Sciences and Resources, China University of Geosciences, Beijing 100083, China. \\ ${ }^{2}$ School of Tourism, Hebei University of Economics and Business, Shijiazhuang 050061, China. \\ ${ }^{*}$ Corresponding author. e-mail: wufd@cugb.edu.cn
}

Developed in the Anxi-Dunhuang basin, the yardangs of Dunhuang (western China) are clearly affected by tectonic movement. Based on fieldwork, this study ascertained three levels of river terrace in the area for the first time. Through the analysis of river terraces formation and regional tectonic movement, the study ascertained that the river terraces were formed mainly by Late Pleistocene tectonic uplift, which had activated the evolution of yardangs in the study area. By electron spin resonance (ESR) dating and optically stimulated luminescence (OSL) dating, the starting time and periodicity of the evolution of the yardangs were determined. The river terraces designated T3, T2 and T1 began to evolve at 109.0 98.5, $72.9 \sim 66.84$ and $53.2 \sim 38.0 \mathrm{kaBP}$, respectively, which is the evidence of regional neotectonic movement. And, the formation of the yardangs was dominated by tectonic uplift during the prenatal stage and mainly by wind erosion in the following evolution, with relatively short stationary phases. This research focused on the determination of endogenic processes of yardangs formation, which would contribute to further understanding of yardangs formation from a geological perspective and promote further study of yardang landform.

\section{Introduction}

A yardang is generally defined as a typical landform of semi-arid to arid areas that is composed of Early to Middle Pleistocene fluvial and lacustrine sediments, formed under the effects of significant wind erosion besides various other factors (Riser 1985; Hassan et al. 2001; Brookes 2003; Goudie 2007; Xia 2007; Al-Dousari Ali et al. 2009; Charlie et al. 2009; Wang and Ha 2009; Chen et al. 2013). Many previous researchers world over have studied them in detail and have established its definition, classification and development (Chen 1936; Ward 1984; Halimov and Fezer 1989; Cooke et al. 1993; Brookes
2001; Qu et al. 2004; Dong et al. 2012). Studies on yardangs under periglacial climates, the application of HiRISE cameras and the discovery of this kind of landform on Mars and Mercury have promoted further research on yardang landform greatly (Ehsani and Quiel 2008; Bridges et al. 2010; de Silva et al. 2010; Sebe et al. 2011).

The evolution of yardangs in Dunhuang underwent prenatal stage, embryonic stage, adolescent stage, mature stage, recession stage and extinct stage, which was influenced by many factors including components, fluvial erosion, wind erosion and gravity (Gutiérrez-Elorza et al. 2002; Zheng et al. 2002; Xia 2007; Dong et al. 2011; Niu et al. 2011; Qu

Keywords. Yardangs; Late Pleistocene; tectonic movement; river terrace; dating. 
et al. 2014). Among these, the endogenic process plays an irreplaceable role during the first two periods. Chronology of yardangs has been a difficulty and is still a problem requiring further study. Niu et al. (2013) considered the formation time of yardangs in Dunhuang as ranging from $39.15 \pm 3.88$ to $10.87 \mathrm{kaBP}$, based on the combination of estimated current wind erosion rates and optically stimulated luminescence (OSL) dating.

To date, there have been many descriptions of the features of yardangs and their environment in Dunhuang (Dong et al. 2012; Niu et al. 2013). Zheng et al. (2002) studied the morphology and formation time of yardangs, west of the Yumenguan Pass (basically the same study area with this study), through contrastive analysis, having referred the effect of tectonic movement. However, the effects were not dealt with in detail. A landform is a product of endogenic and exogenic processes, which holds true for yardangs. This study details the periodicity of tectonic uplift and its effect on yardangs formation by investigating three river terraces and the faults. The starting time of the periodic formation was deduced based on electron spin resonance (ESR) and OSL tests. The results suggest that there were three periods of tectonic uplift, having activated the formation of three periods of yardangs. Intensive study of the action of tectonic uplift would contribute to further understanding of yardangs formation from a geological perspective and promote further study of this special landform.

\section{Study area}

The study area is located in the north-west of Dunhuang, Gansu Province of China (figure 1), and is $160 \mathrm{~km}$ from urban Dunhuang. It experiences an extremely arid temperate zone climate with droughts, little precipitation, strong evaporation, cold winters and hot summers. The site is situated to the south of Mount Beishan, north of the Altun Mountains, and in the faulted AnxiDunhuang basin, which was formed during the Cenozoic (Guo and Zhang 1998). There are some concomitant mini-faults that developed in the Quaternary strata within the basin, showing features of regional neotectonic movement (Wang 1990).

The study area is part of the ancient Lop Nur and is located in the north-east of Aqik Valley, in the northern area of the lower reaches of the ancient Shule River (Feng 1981). Research shows that the ancient Shule River ran west through Aqik Valley in the past and shifted under the effect of later tectonic movement (E Y H et al. 2006). In terms of stratigraphy, it belongs to the Gansu Corridor, where Quaternary sediments of different periods and types have developed (Cao 1997; Zhao et al. 2009), which are the main components of yardangs. These sediments include unconsolidated fluvial and lacustrine sand, mud or clay, in which sedimentary structures such as large-scale cross beddings and erosion surfaces have developed. Yardangs have developed an uneven surface under the effects of differential weathering.

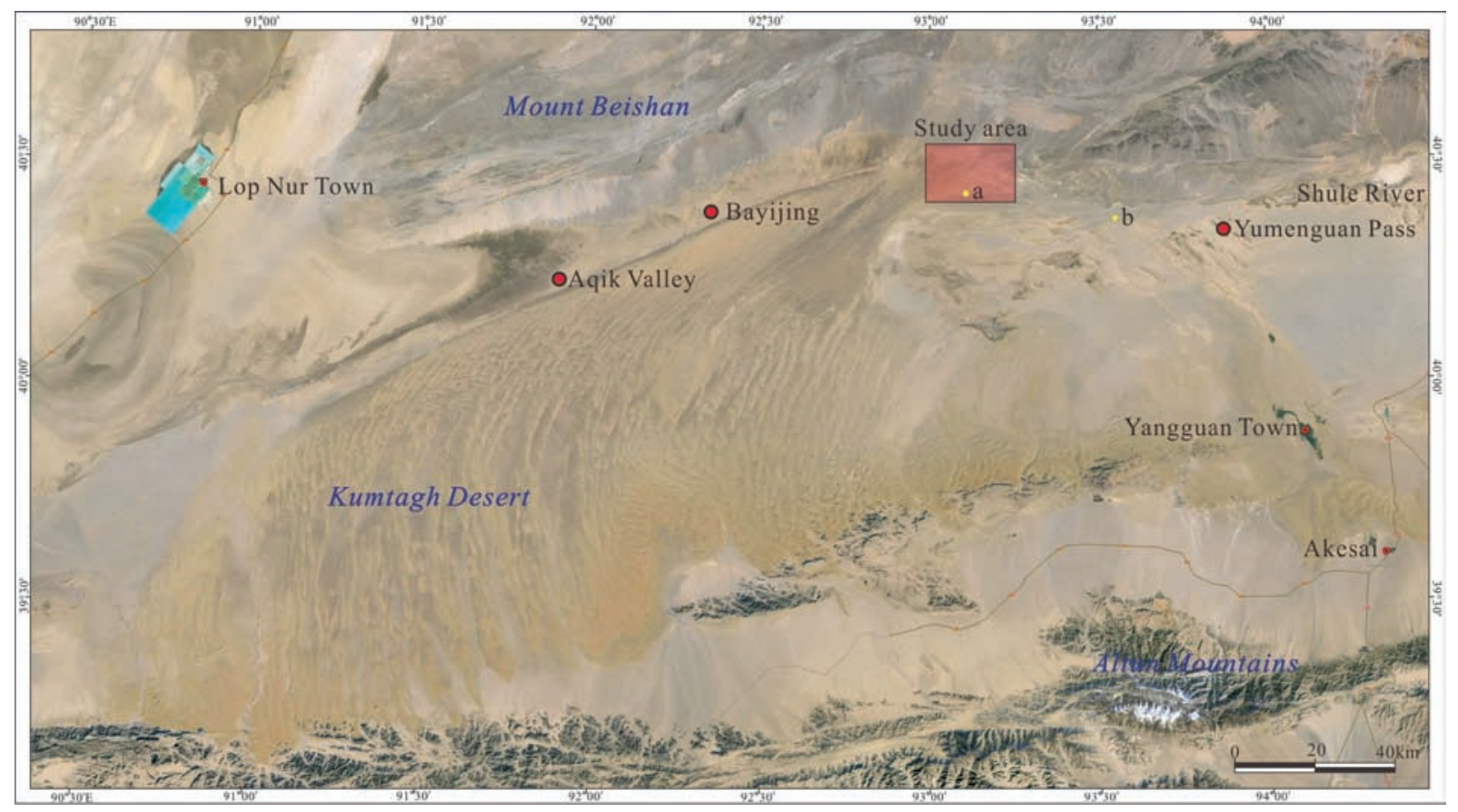

Figure 1. Location of the study area. 


\section{Methods}

\subsection{Field investigation}

\subsubsection{Characteristics of river terraces}

The formation of a river terrace is controlled by several factors. In general, there are three types of river terraces, e.g., erosion terrace, base terrace and constructional terrace (Cheng 2009; Tian and Cheng 2009), among which the base terrace forms due to the crustal uplifting and river downcutting, with the rising height thicker than the sediment thickness (Bull 1990). Three levels of terraces were found in the study area during the field investigation, covered with sandy gravel and extending laterally from tens to hundreds of meters (figure 2). Elevation differences of the river terrace were measured: T1 measures about $24 \mathrm{~m}$ over the modern erosion surface on average; the mean elevation difference between $\mathrm{T} 1$ and $\mathrm{T} 2$ is about $28 \mathrm{~m}$; the mean elevation difference between T2 and T3 is about $18 \mathrm{~m}$.

At location No.1 in figure 2, a sandy gravel layer with a thickness of about $1 \mathrm{~m}$ was found deposited unconformably on Middle Pleistocene lacustrine sediments (figure 3(1)). The sandy gravel layer is unconsolidated and dominated by gravel interbedded with sand layers and lenses of sand. The diameter of the gravel ranges from 1 to $5 \mathrm{~cm}$, and it is well-sorted and rounded. The matrix of the gravel layer contains medium to coarse sand. The sand lenses are mainly composed of medium sand, with a maximum thickness of $70 \mathrm{~cm}$, and extends laterally to 5-6 m. Gravel lenses also show their lateral extent of about 3-4 m (figure 4a). Dispersion of the valley, characteristics of the sediments and the unconformity between strata show that it is mostly the $\mathrm{T} 1$ river terrace.

Underlying formation of the terrace is composed of fine-to-medium sand interbedded with clay layers, and the upper part of the underlying strata is a clay layer measuring $50 \mathrm{~cm}$ thick, which has collapsed to the south-west with gravel filling in the fractures at location No. 2 shown in figure 2. The clay layer was eroded into pieces (figure 3(2)). Sandy gravel layers were deposited over the erosion surface, with some of them at the bottom possessing diameters of $0.8-3 \mathrm{~cm}$. These layers are overlain by fine-grained sediments and boulder fragments with scattered gravels measuring $8-15 \mathrm{~cm}$ in diameter (figure $4 \mathrm{~b}$ ). On top of the erosion, the surface is a medium sand layer with gravel, in which cross beddings have developed. The characterization of sediments described above was considered part of the $\mathrm{T} 1$ river terrace. The platform at location No. 3 in figure 2 trended along the direction of $\mathrm{ES} 100^{\circ}$, and its artificial section (figure 4c) shows that the sediments are composed of sand layers and sandy gravel layers deposited unconformably above the underlying formation (figure 3(3)). Graded beddings could be found in the sediments. Taking the features (sedimentary characteristics, relative elevation and other factors included) into account, this platform probably constituted the T2 river terrace.

The platform at location No. 4 had a sandy gravel layer at the bottom, with a thickness of 0.8-1.2 $\mathrm{m}$, an average thickness of $1 \mathrm{~m}$, and directional arrangement of gravels. The gravels are well sorted, and sub-rounded to rounded (figure 3(4)), with diameters mostly varying from 0.5 to $5 \mathrm{~cm}$ and a maximum diameter of $8 \mathrm{~cm}$. Gravels are composed of mudstone, vein quartz, granite, sandstone, gneiss, etc. Sand lenses and boulders of clay developed in the gravel layer. Gravels exhibited a normal grading from bottom to top, overlying unconformably on the clay layers (figure 4d). Based on the sedimentary characteristics and the elevation difference, this platform should be the third river terrace (T3).

\subsubsection{Active fault}

At the south border of yardangs distribution (location a in figure 1), there is an obvious fault developed, extending east to west. The hanging wall is composed of Middle Pleistocene muddy layers interbedded with sandy layers, with a maximum dip angle of $60^{\circ}$, and the strata turn into horizontal to the north (figure 5). The footwall of the fault is Upper Permian metamorphous volcanic

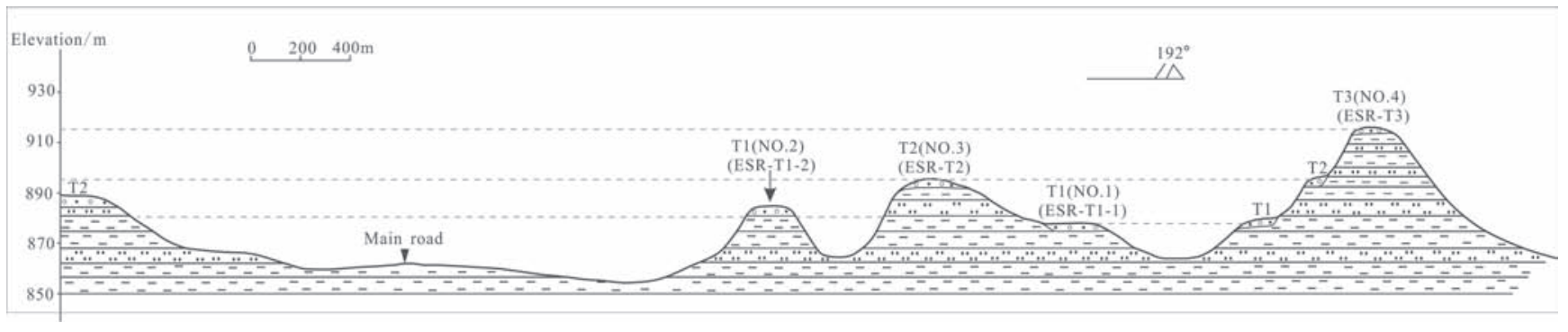

Figure 2. Three levels of investigated river terrace in the study area (for legends, please see figure 3). 


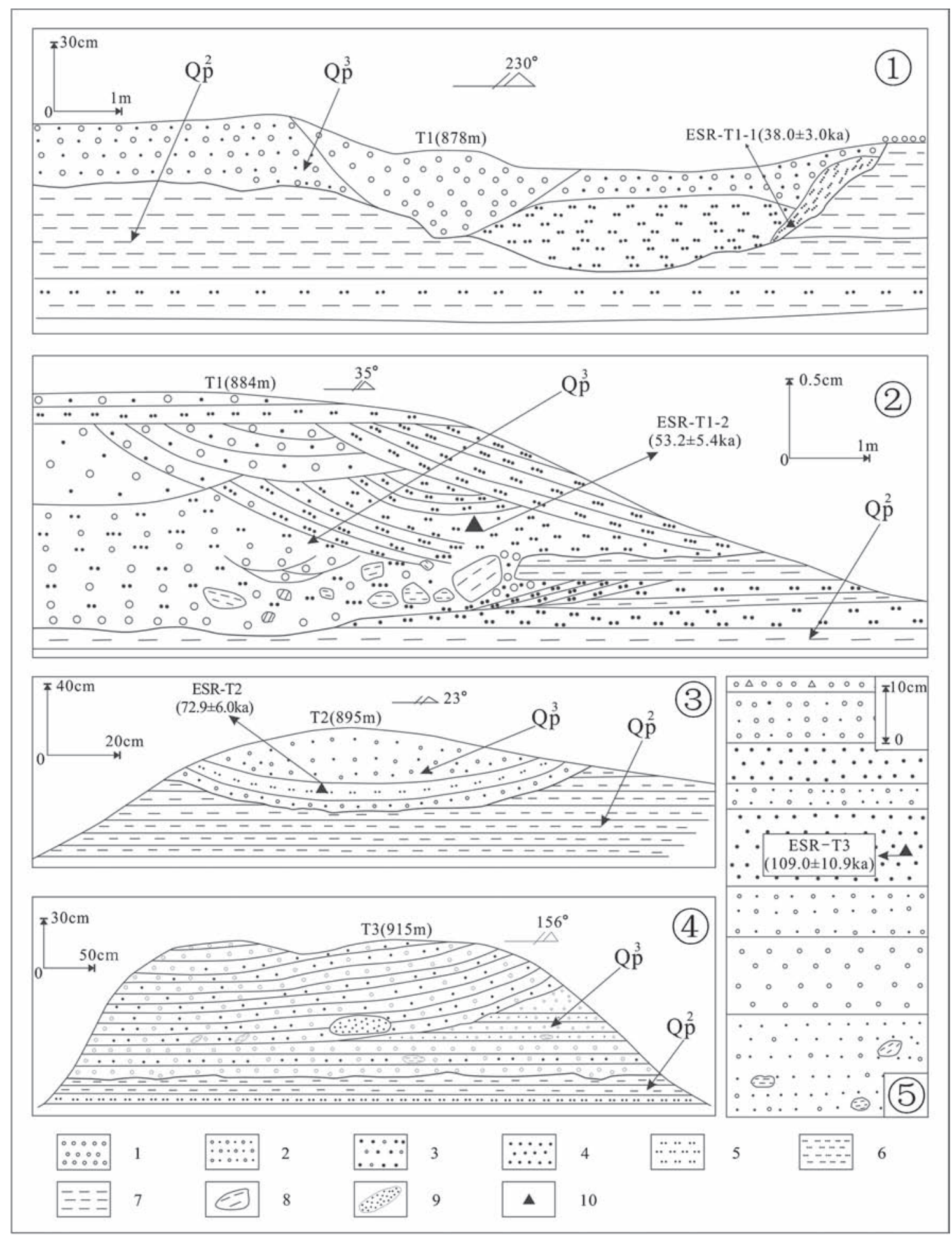

Figure 3. Sedimentary characteristics of river terraces: (1) gravel layers, (2) fine gravel layers with sand, (3) coarse sand layers with gravel, (4) coarse sand layers, (5) medium sand layers, (6) fine sand layers, (7) muddy layers, (8) fragments of clay, (9) lenses of sand and (10) sampling point.

rocks. Tectonic movements had a limited effect on the yardang strata, about $150 \mathrm{~m}$ in maximum deformed. And, there are many associated faults, slickenside and fault gouge developed near the main fault, the fault gouge is about $20 \mathrm{~cm}$ wide. Taking the relation between the fault plane and the lithology on both sides, features of the slickenside and landforms, the fault is probably a normal fault with the footwall uplifted and hanging wall relatively descended.

\subsection{Dating}

Sediments of river terraces are good materials for chronological study. Thus, we chose fine sand, 


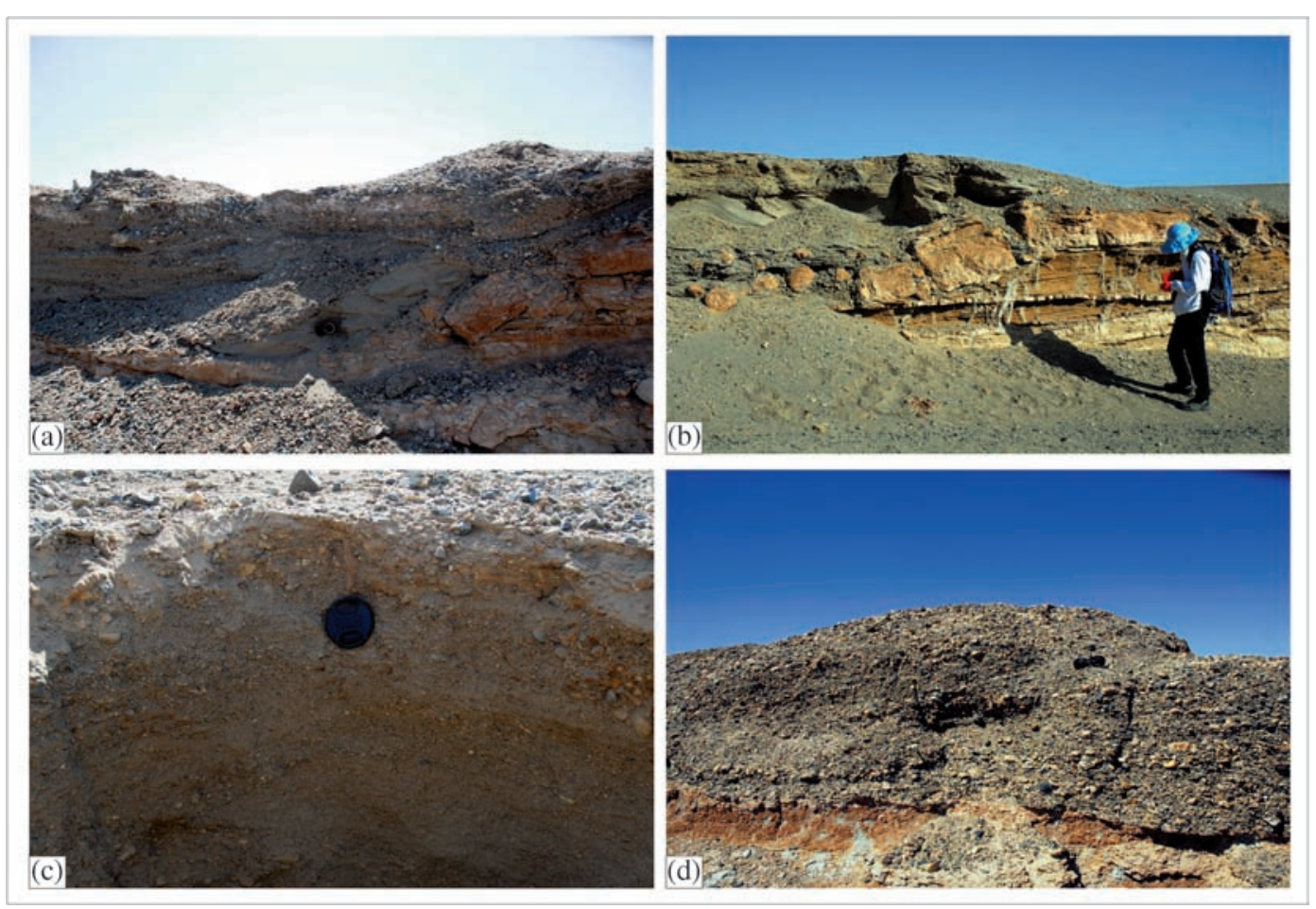

Figure 4. Photographs of sedimentary characteristics of T3 through T1 river terrace: (a) sediments of T1 river terrace, (b) sediments of another location of $\mathrm{T} 1$ river terrace, (c) sediments of artificial section of T2 river terrace, and (d) sediments of $\mathrm{T} 3$ river terrace.

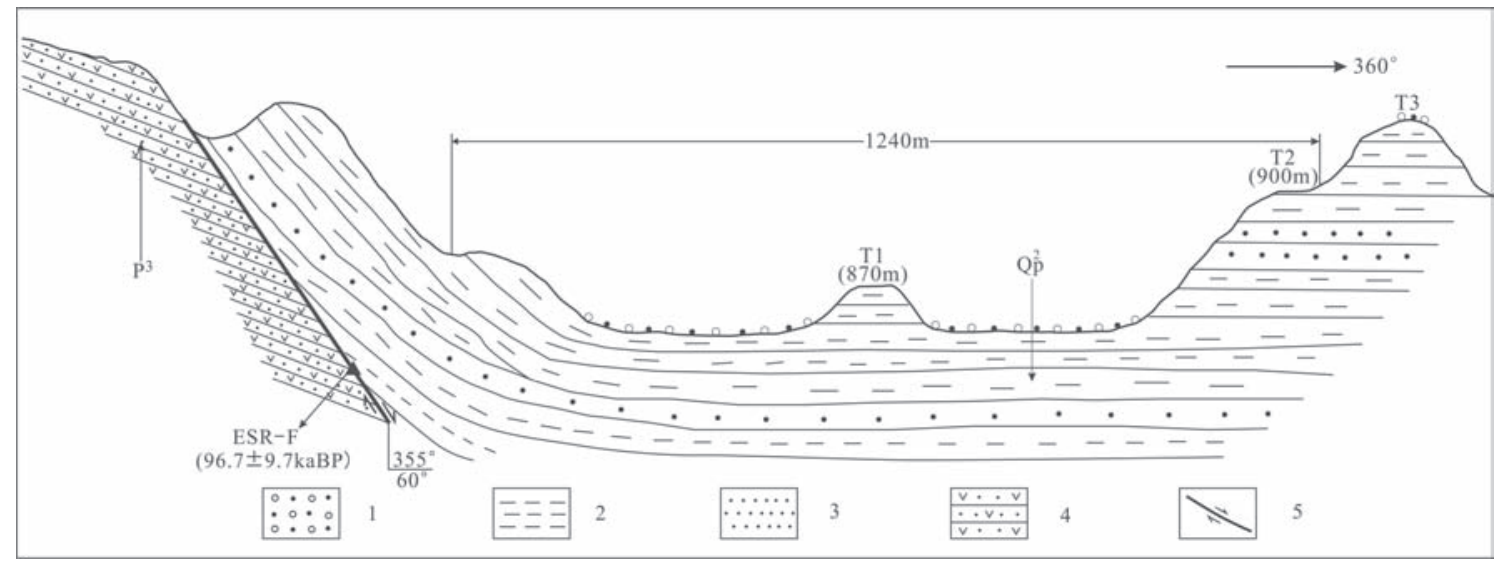

Figure 5. Profile of the fault and yardangs. (1) Sand gravel; (2) muddy layer; (3) sandy layer; (4) metamorphous volcanic rocks; and (5) the fault plane and its moving directions.

medium sand and coarse sand on the top of T3 through $\mathrm{T} 1$ as the samples for dating, eight samples were collected from sediments of T3 through T1 and the fault. To protect them from sunlight, friction and heat, the samples were packed in steel pipes sealed with black plastic bags.

ESR dating was selected for dating most of the river terraces, with the aim of designating the periodicity and starting time of yardang formation. Among the samples, sediments from T2 were tested with ESR and OSL methods for comparison.

ESR test was completed at the Chengdu University of Technology. Quartz and calcium carbonate grains grading from 0.2 to $0.125 \mathrm{~mm}$ were selected for testing. The test conditions were as follows: room temperature of $20^{\circ}-25^{\circ} \mathrm{C}$; microwave frequency of $9.7652 \mathrm{GHz}$; microwave power of 0.21-0.30 mW; amplitude modulation of $0.25 \mathrm{Gpp}$; modulating frequency of $100 \mathrm{kHz}$; amplification coefficient of $5 \times 10^{5}$; time constant of $50 \mathrm{~ms}$; and central magnetic field of $3500.0 \mathrm{G}$. The dating signal of calcium carbonate was detected at $3498.0 \mathrm{G}$, the dating signal of quartz E' was detected at 3505.0 G, and the dating signal of Ge was detected at $3506.0 \mathrm{G}$. OSL test was completed by Institute of China Seismological Bureau Crustal Stress. 


\section{Results}

The results are presented in tables 1 and 2 . The ESR signals of quartz and calcium carbonate sediments can be measured by the correlation coefficient. The closer to 1.000 the correlation coefficient is, the stronger the signal strength is, and the more accurate the result will be. During testing, the correlation coefficient hardly equals to 1.000 due to measurement error. However, the result could be considered authentic when it is over 0.800. Most of the correlation coefficients in this study were over 0.900 (table 1 ), indicating that the results can represent the actual age of sedimentation or tectonic movement. The OSL result was evaluated by the test centre.

We can conclude that the ages of the river terraces are approximate and within the range of the Late Pleistocene $\left(\mathrm{Qp}^{3}\right)$. ESR-T3 was obtained from the top of T3, which could represent the approximate starting time of T3 formation, with an age of 109.0 $\pm 10.9 \mathrm{kaBP}$. ESR-T3-1 was obtained from another location of T3 near the museum, with the result of $96.7 \pm 10.0 \mathrm{kaBP}$. ESR-T2-1 was obtained from the top of T2 (medium sand), with an age of $72.9 \pm 6.0 \mathrm{kaBP}$ that can be correlated to the starting time of T2 formation. OSL-T2-2 was also obtained from the same terrace with ESR-T2-1, with an age of $66.84 \pm 7.35 \mathrm{kaBP}$. ESR-T1-1 and ESR-T1-2 were obtained from the fluvial fine sand layer and the sand lens of $\mathrm{T} 1$, with the result of $38.0 \pm 3.0 \mathrm{kaBP}$ and 53.2 $\pm 5.4 \mathrm{kaBP}$. ESR-T13 (coarse sand) was from $\mathrm{T} 1$ in the south of the study area, similar elevation with $\mathrm{T} 1$ in the north area, with a result of $43.0 \pm 4.0 \mathrm{kaBP}$. These sediments are similar in age to a previous study of $43.58 \pm 2.32 \sim 34.46 \pm 5.24 \mathrm{kaBP}$ (Niu et al. 2013), so they could represent the starting time of $\mathrm{T} 1$ formation. ESR-F was got from the fault gouge, indicating the formation time of the fault was about $96.7 \pm 9.7 \mathrm{kaBP}$, which is basically the approximate time of $\mathrm{T} 3$ formation.

\section{Discussion}

\subsection{Formation of river terraces}

\subsubsection{Terrace formation and climate change}

Factors driving river terraces development consist of changes in the internal dynamics of the fluvial system and external influence of the fluvial system; the latter include climate change and tectonic movement. A river terrace formed mainly by the internal fluvial system is usually in a very small scale; thus, when studying a fluvial geomorphologic evolution over a long time and large spatial scales, the internal dynamics could be neglected

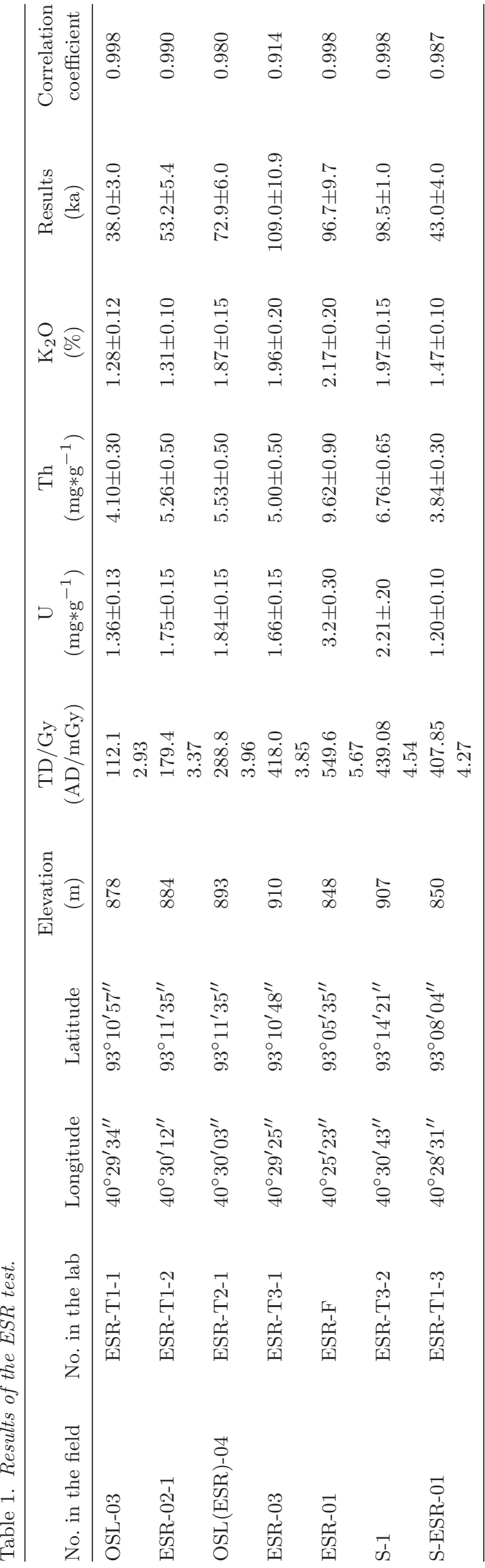


(Maddy et al. 2001a). By comparing the formation time of yardangs with the climate change in Late Pleistocene (figure 6), we can see that the formation time of T3, T2 and T1 were more or less in the cold period. Sediments of the river terrace are mostly thin layers, approximately $0.5-2 \mathrm{~m}$ thick, which indicates that the tectonically stable stage is relatively short.

Generally in the climate-driven terrace, during the period of warm or transition from cold to warm period, the fluvial system is dominated by downcutting, whereas sedimentation would dominate during the cold periods or transition from warm to cold period, developing thick layers of fluvial sediments (Maddy et al. 2001b). The starting times of T3, T2 and T1 were almost in the cold period or the transition period from warm to cold, during which the sedimentation should have dominated. So, the thin sedimentation happened to illustrate terraces in the study area, formed with little effect due to climate change. Moreover, climate-driven terrace usually develops symmetrical along the riverbed (Cheng 2009), while river terraces in the study area developed almost asymmetrically along each valley, with fine and rounded gravel, suggesting that there are more factors except the little effect of climatic factors on its formation. And, it could be further proved that the starting of yardangs was affected by tectonic movement. Therefore, we could infer that there were three apparent periodic lifting events forming the T3 through T1 river terraces.

\subsubsection{Representation of regional tectonic movement}

The main faults of the East Arkin Tectonic System constitute mountains and the boundaries of the Dunhuang Basin, including faults at the northern and southern boundaries of the study area. ESR testing shows that the southern fault formed about $96.7 \pm 9.7 \mathrm{kaBP}$, more or less identical with the formation time of $\mathrm{T} 3$ terrace, which illustrates that there were regional tectonic movements about 100 thousand years ago. Besides, the regional neotectonic movement was proved to be inherited and limited to the previous tectonic movements, appearing uplifted in a large scale before Middle Pleistocene and intermittent uplifted after Middle Pleistocene during when faults developed (Gao et al. 2015). What is more, several levels of river terraces developed in different areas along Arkin Mountains since $103 \mathrm{kaBP}$, e.g., during 35 42, 45 53, 65 78 and $103 \mathrm{kaBP}$ (Zheng 2005), identical to the result obtained in this study, thus increasing the reliability of the model where river terraces in the study area were formed mainly under the effect of Late Pleistocene tectonic movement.

To the south-east of the study area, west of Yumenguan Pass (location b in figure 1), a distinct 


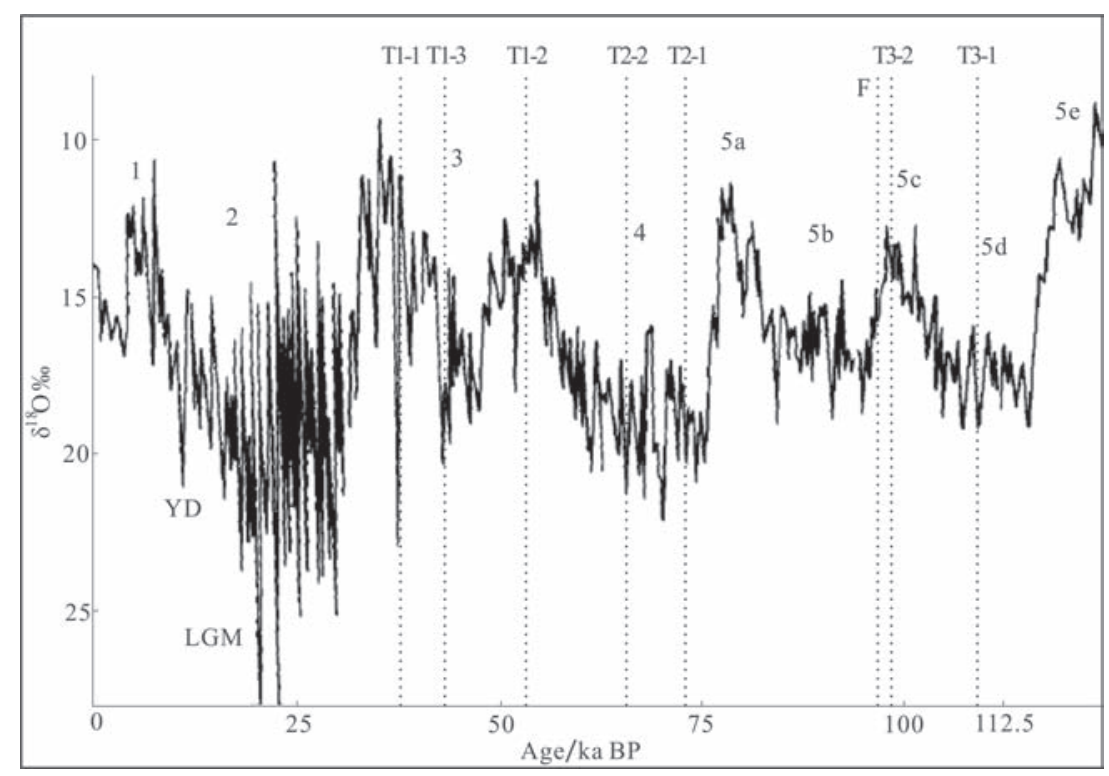

Figure 6. Relationship between formation of river terraces and climate change in Late Pleistocene (according to Yao et al. 1997): (1) post glacial, (2) late stage of the last glacial, (3) interglacial epoch of the last glacial, (4) early stage of the last glacial, (5) last interglacial period; YD: Younger Dryas, LGM: last glacial maximum.

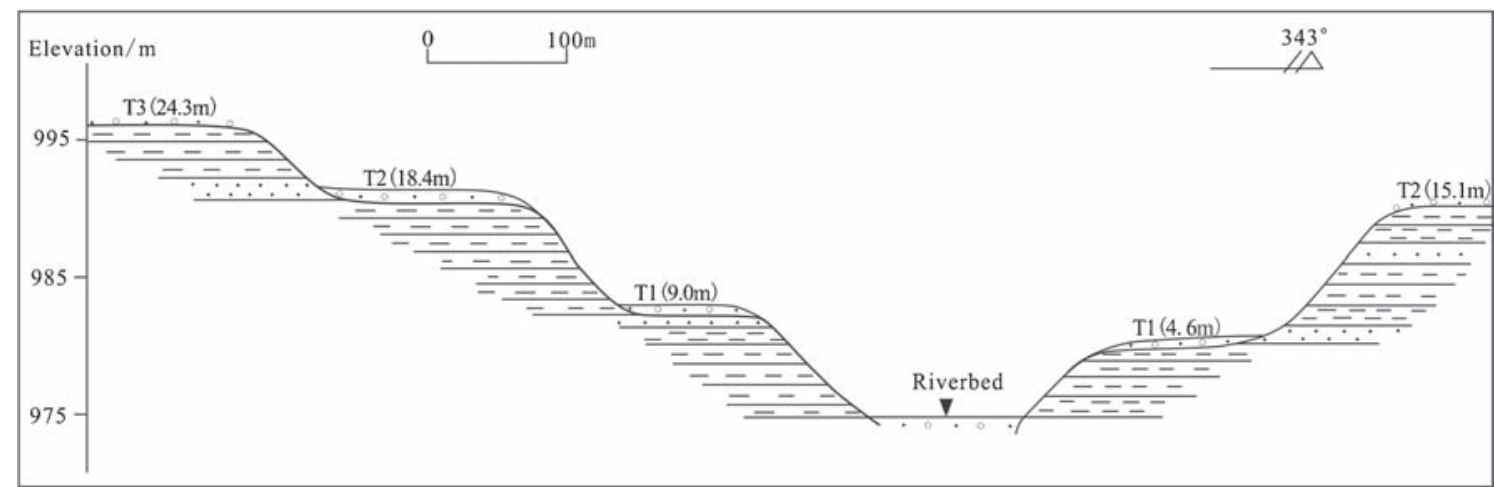

Figure 7. Cross section of the Shule River terrace to the west of Yumenguan Pass (for legends, please see figure 5).

river terrace developed, distributing along both sides of the Shule River (figure 7). Two levels of terrace have developed on the northern bank of the river, where the average elevations of $\mathrm{T} 2$ and $\mathrm{T} 1$ are $4.6 \mathrm{~m}$ and $15.1 \mathrm{~m}$, respectively. Three levels of terraces developed on the southern bank of the river, and the average elevations for $\mathrm{T} 3, \mathrm{~T} 2$ and $\mathrm{T} 1$ were measured to be $9.0 \mathrm{~m}, 18.4 \mathrm{~m}$ and $24.3 \mathrm{~m}$, respectively. Sediments of the terrace are similar to those of the study area in sediments and sedimentary features, essentially belonging to the base terrace that is composed of the underlying Quaternary fluvial and lacustrine muddy layers covered by fluvial sediments. These river terraces could be products of the Late Pleistocene tectonic movement.

\subsection{Analysis of the dynamics of yardangs formation}

The dynamics that controlled the development of yardangs include endogenic and exogenic geological processes. The former controlled the rates, ranges, periodicity and the entire development process of yardangs formation; the latter moulded the shapes of the yardangs and promoted their evolution. It was tectonic movement that uplifted the fluvial and lacustrine sediments and started the yardang erosion.

Since the Late Pleistocene, tectonic movement was the primary endogenic geological process, whereas fluvial erosion and wind erosion were the main exogenic processes (Xia and Zhao 2005; Niu et al. 2013). The significance of fluvial erosion in the development of yardangs has been noted by many researchers, some of them identified three types of yardangs in Lop Nur region of China, including those dominated by wind erosion, those dominated by fluvial erosion and those dominated by reworking of wind erosion and fluvial erosion (Krinsley 1970). Thus, the role of fluvial erosion should not be neglected in the study of yardangs formation in Dunhuang. 
The effects of fluvial erosion on yardang development can be summarised into two aspects: one is to affect the trend of a yardang by eroding along joints (or cracks) at the initial stage of yardang evolution, and the other is to accelerate the erosion. Wind erosion is the main factor shaping yardangs, including the rubbing-abrading action, and deflation, where the former played an important role and usually occurred near the ground. Thus, many wind erosion gullies can be found on the windward side of the yardangs. Collapses caused by gravity is another factor that leads to the decline of yardangs.

\subsection{Relationship between river terraces and yardangs}

Yardangs in Dunhuang are found within a contiguous area of about $400 \mathrm{~km}^{2}$, exhibiting an alternative distribution of yardangs and gullies in Gobi. Yardangs occur between two faults from the north and the south ridges. Layers become deformed because of the Pleistocene tectonic movement, appearing more distinctly at the southern boundary (figure 8a).

The occurrence of yardangs was activated by the neotectonic movement at the very beginning of
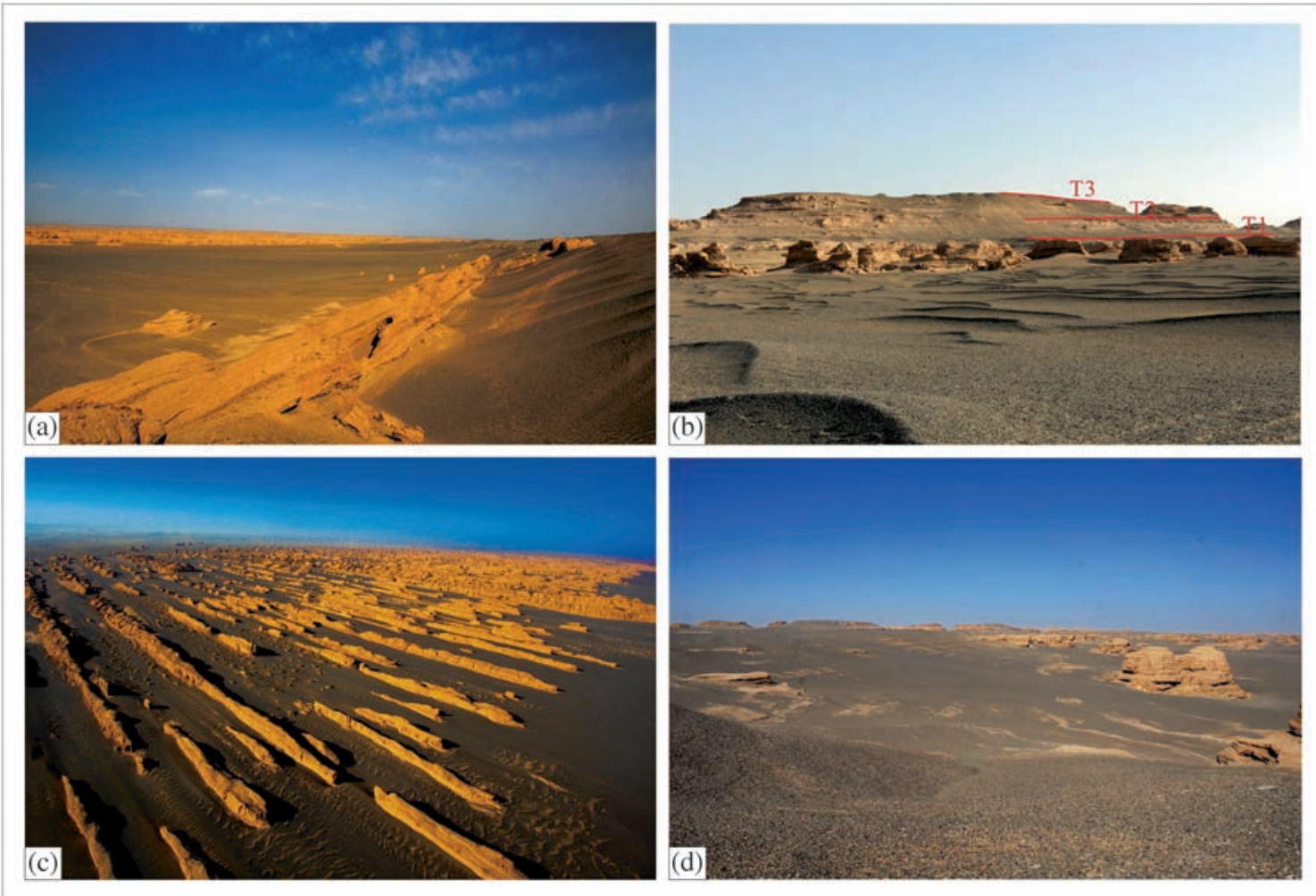

Figure 8. Pictures revealing the relationship between the occurrence of yardangs and river terraces: (a) deformed yardang, (b) three levels of river terrace relevant to the yardangs, (c) yardangs coincide with T1 river terrace in the height, and (d) T3 river terrace and yardangs.

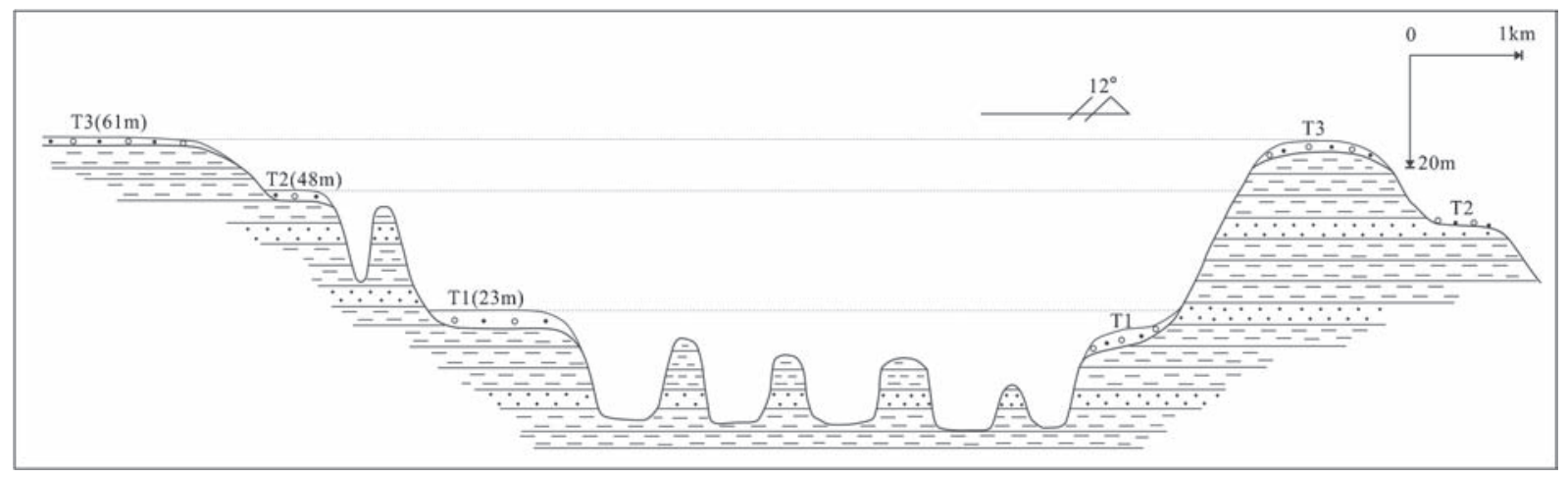

Figure 9. A section reflecting the relationship between river terraces and yardangs (for legends, please see figure 5). 
its evolution. The tectonic movement appeared as three levels of river terrace in geomorphology. The heights of the yardangs appeared to coincide to the three river terraces, which were discovered during the field investigation (figure $8 \mathrm{~b}$ ). This may be an evidence that neotectonic movement regulated the development of yardangs. Among the yardangs, those with heights similar to T1 showed the widest distribution and the greatest number of types (figure 8c). Those developed in association with T2 were more or less destroyed, with few yardangs near T2. Yardangs coinciding with T3 in the height were rare, most of which were eroded and destroyed, and only yardangs of the infantile stage could be found in the vicinity of T3 (figure 8d). Though the formation of yardangs is periodic, they may form simultaneously sometimes, which may account for why there are yardangs of different periods coexisting. The relationship between typical river terraces and yardangs is shown in figure 9 .

\subsection{Effect of Late Pleistocene tectonic movement on the formation of yardangs}

Mount Beishan was uplifted under the effect of Himalayan movement, causing the ancient lake to disappear and the strata to be exposed to air, which constituted the components basis of the yardangs (Zheng et al. 2002). The evolution of yardangs may include prenatal stage, embryonic

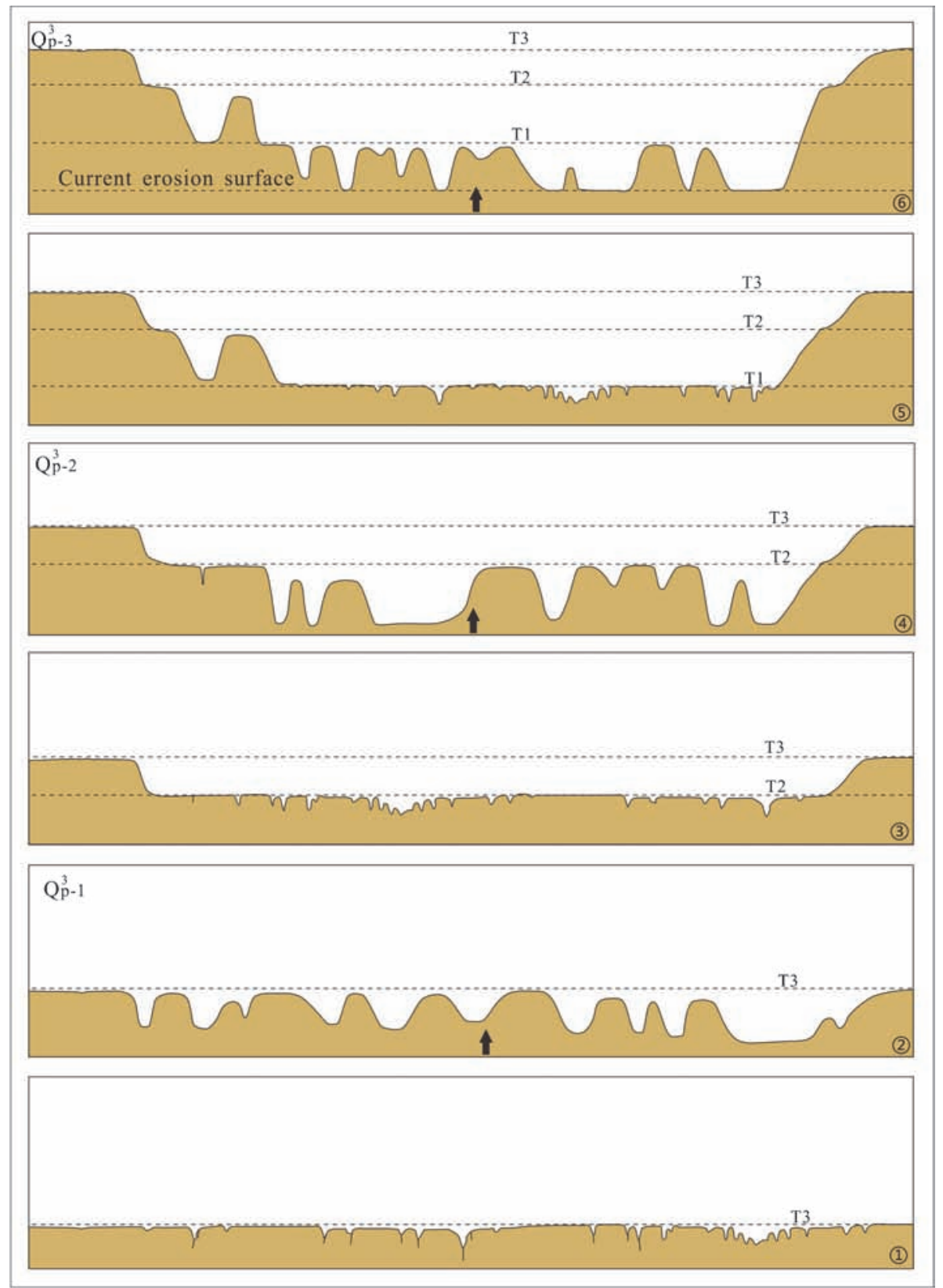

Figure 10. Diagram of yardang evolution affected by Late Pleistocene tectonic movement. 
stage, adolescent stage, mature stage, recession stage and extinct stage, which should be periodical, under the same conditions. The evolution of a yardang can be reconstructed by correlating the three levels of yardangs distribution, which developed on the basis of tectonic uplift, which has caused river terrace formed in the study area. Yardangs in the study area may have three periods of development since Late Pleistocene.

T3 formed because of uplift and river downcutting, which were affected by tectonic movement since 109.0 $\pm 10.9 \sim 96.7 \pm 10.0 \mathrm{kaBP}$ (figure 10 (1)), during which vertical fissures and cracks developed in the strata. This can be considered the prenatal stage. Over time, yardangs entered a stage during when they developed mainly by exogenous processes after tectonic movement became stable. At first, the gullies formed through fluvial and wind erosion along fissures and cracks, resulting in the initial morphology; then, wind erosion became the key factor, causing the gullies to deepen and widen, and large-scale yardangs formed; further wind erosion resulted in yardangs with distinct shapes (figure 10(2)). Over the time, erosion and collapse caused some of the yardangs to be damaged until they disappeared from the landscape; the entire process of yardang evolution lasted for approximately $36 \mathrm{ka}$.

During approximately $72.9 \pm 6.0 \sim 66.84 \pm 7.35 \mathrm{kaBP}$, the crust uplifted again, leading to erosion as the base level descended and T2 formed (figure 10(3)). The second occurrence of yardang formation began under the effects of tectonic movement, fluvial erosion and wind erosion (figure 10(4)). During $53.2 \pm 5.4 \mathrm{kaBP}$ and $38.0 \pm 3.0 \mathrm{kaBP}$, the earth's crust uplifted once more (figure 10 (5)), the erosion base level descended again, and the fluvial and lacustrine sediments were eroded by exogenous processes. Thus, the third period of yardang evolution occurred (figure 106). Through all the time that T3 to T1 formed, yardangs never stopped to evolve, resulting in the current distribution.

The yardang landform formed on the basis of the lacustrine and fluvial sediments, constituting the base of the river terraces. It was the tectonic movement that allowed the formation of the river terrace and activated the formation of yardang landform. The lacustrine and fluvial sediments were exposed to the surface by tectonic uplift and eroded by water and wind into various morphologies.

\section{Conclusions}

There have been three levels of river terrace in the study area since the Late Pleistocene. Tests of the sediments on the top of each terrace show that sediments of T3, T2 and T1 began to accumulate since $109.0 \pm 10.9 \sim 98.5 \pm 1.0,72.6 \pm 6.0 \sim 66.84 \pm 7.35$ and 53.2 $\pm 5.4 \sim 38.0 \pm 3.0 \mathrm{kaBP}$ respectively, which means T3, T2 and T1 were formed approximately at $\quad 109.0 \pm 10.9 \sim 98.5 \pm 1.0, \quad 72.6 \pm 6.0 \sim 66.84 \pm 7.35$ and 53.2 $\pm 5.4 \sim 38.0 \pm 3.0 \mathrm{kaBP}$.

During the formation of the three terraces, the stable tectonic stage was relatively short, with little effect due to climate change. Tectonic uplift and river downcut were the main factors affecting terrace development.

Tectonic movement of Late Pleistocene led the sediments to be uplifted, which constituted the trigger that yardang began to form by fluvial and wind erosion. In geomorphology, three levels of river terraces reflected the three periods of yardang formation, causing three periods of yardangs to form. Yardangs of the first stage, formed from $109.0 \pm 10.9 \sim 98.5 \pm 1.0$ to $72.6 \pm 6.0$ kaBP, have more or less been eroded away; those of the second stage, from $72.6 \pm 6.0 \sim 66.84 \pm 7.35$ to $53.2 \pm 5.4 \mathrm{kaBP}$, were mostly damaged with some of the initial stage left near T2; yardangs of the third stage began at $53.2 \pm 5.4 \sim 38.0 \pm 3.0 \mathrm{kaBP}$. These yardangs constitute the current distribution of the landforms in the study area.

\section{Acknowledgements}

The authors would like to thank the Bureau of Land and Resources of Dunhuang and the Administration for Yardang National Geopark of Dunhuang for their valuable help during the field investigations; they also thank Prof. Mingzhong Tian and Prof. Jianping Zhang for their advice; thanks are extended to Xin Yuan, Xiao Mei, Wenbin Cao and Yanlong $\mathrm{Yu}$, who contributed their share in the field; to the Institute of Crustal Dynamics of China Earthquake Administration and the Institute of Nuclear Technology of Chengdu University of Technology for sample test, and to the reviewers who have proposed very good suggestions.

\section{References}

Al-Dousari Ali M, Al-Elaj M, Al-Enezi E and Al-Shareeda A 2009 Origin and characteristics of yardangs in the Um Al-Rimam depressions (N Kuwait); Geomorphology 104 93-104.

Bridges N T et al. 2010 Aeolian bedforms, yardangs, and indurated surfaces in the Tharsis Montes as seen by the HiRISE Camera: Evidence for dust aggregates; Icarus 205 165-182.

Brookes I A 2003 Geomorphic indicators of Holocene winds in Egypt's western desert; Geomorphology 56(1/2) 155-166.

Brookes I A 2001 Aeolian erosional lineations in the Libyan Desert, Dakhla Region, Egypt; Geomorphology 39 189-209.

Bull W B 1990 Stream-terrace genesis: Implications for soil development; Geomorphology 3 351-367.

Cao X S 1997 Quaternary of Gansu; Acta Geologica Gansu 02 2-4, 6-30, 32-41, 43-44 (in Chinese).

Charlie W A, Allard D J and Doehring D O 2009 Pile settlement and uplift in liquefying sand deposit; Geotech. Test. J. 32(2) 147-156. 
Chen Z Q 1936 Lop Nor and Lop Desert; Acta Geographica Sinica 3(1) 19-49 (in Chinese with English abstract).

Chen A Z, Lu Y T, Zhang E K and Tian M Z 2013 A grand tourism earth-science dictionary; Science Press, Beijing (in Chinese with English abstract).

Cheng J 2009 Practice book of Quaternary geology and geomorphology; Geological Publishing House, Beijing (in Chinese).

Cooke R U, Warren A and Andrew S G 1993 Desert Geomorphology; London UCL Press.

de Silva S L, Bailey J E, Mandt K E and Viramonte J M 2010 Yardangs in terrestrial ignimbrites: Synergistic remote and field observations on earth with applications to Mars; Planet. Space Sci. 58 459-471.

Dong Z B, Lv P, Lu J F, Qian G Q, Zhang Z C and Luo W Y 2012 Geomorphology and origin of Yardangs in the Kumtagh Desert, Northwest China; Geomorphology 139$140145-154$.

Dong Z B, Su Z Z, Qian G Q, Luo W Y, Zhang Z S and Wu J F 2011 Aeolian Geomorphology in the Kumtagh Desert; Science Press, Beijing, pp. 292-309 (in Chinese with English abstract).

E Y H, Su Z Z, Wang J H, Zhai X W, Liu J H, Tang J N, Ding F, Zhang J C, Liao K T and Zheng Q Z 2006 Outcome and scientific significance of integrated investigation in Kumtag Desert; J. Desert Res. 5 693-697 (in Chinese with English abstract).

Ehsani A H and Quiel F 2008 Application of Self Organizing Map and SRTM data to characterize yardangs in the Lut Desert, Iran; Remote Sens. Environ. 112 3284-3294.

Feng S W 1981 Evolution of Shule He River System; J. Lanzhou University 4 138-143 (in Chinese with English abstract).

Gao Y M, Wang G R, Zhang C Y and Chen X C 2015 Hydrogeological investigation report of water sources in Dunhuang Yardang National Geopark, Engineering and Exploration Institute of Jiuquan; Gansu Province, pp. 6-12 (in Chinese).

Goudie A S 2007 Mega-yardangs: A global analysis; Geography Compass 1(1) 65-81.

Guo Z J and Zhang Z C 1998 Structural style and tectonic evolution of the basins in the Altun Region; Geol. Rev. 44(4) 357-364 (in Chinese).

Gutiérrez-Elorza M, Desir G and Gutiérrez-Santolalla F 2002 Yardangs in the semiarid central sector of the Ebro Depression (NE Spain); Geomorphology 44 155-170.

Halimov M and Fezer F 1989 Eight yardangs types in central-Asia; Z. Geomorphol. 33(2) 205-217.

Hassan F A, Barich B, Mahmoud M et al. 2001 Holocene playa deposits of Farafra Oasis, Egypt, and their palaeoclimatic and geo-archaeological significance; Geoarchaeology 16(1) 29-46.

Krinsley D B 1970 A geomorphological and palaeoclimatological study of the playas of Iran; U.S. Geological Survey Final Report, Contract No. PRO CP 70-800.

Maddy D, Bridgland D R and Westaway R 2001a Upliftdriven valley incision and climate-controlled river terrace development in the Thames Valley, UK; Quat. Int. 79(1) $23-36$.

Maddy D, Macklin M G and Woodward J C 2001b River basin sediment systems: Archives of environmental change; Balkema, Lisse, 503p.
Niu Q H, Qu J J, Li X Z, Dong G R, Zhang K C and Han Q J 2011 Review and prospect of yardang landform's research; Adv. Earth Sci. 5 516-527 (in Chinese with English abstract).

Niu Q H, Qu J J, Liu L B, Wang J Z, Xie S B and Wang T 2013 Dating methods for chronological study of yardang landforms: A review and perspective in application; Marine Geology \& Quaternary Geology 4 201-208 (in Chinese with English abstract).

Qu J J, Niu Q H and Gao D X 2014 Formation and development processes pattern of Dunhuang Yardang landforms; Geological Publishing House, Beijing (in Chinese).

Qu J J, Zheng B X, Yu Q H and Zhao A G 2004 The yardang landform of Aqik Valley in the east of Lop-Nor and its relationship with the evolution of the Kumtagh Desert; J. Desert Res. 3 40-46, 127-128 (in Chinese with English abstract).

Riser J 1985 Le role du ventau cours des derniers millenaires dans le basin Saharien d'Araouane (Mali); Bulletin de l'Association deGéographes Francais 62 311-317.

Sebe K, Csillag G, Ruszkiczay-Rüdiger Z, Fodor L and Thamó-Bozsó E 2011 Wind erosion under cold climate: A Pleistocene periglacial mega-yardang system in central Europe (western Pannonian Basin, Hungary); Geomorphology 134 470-482.

Tian M Z and Cheng J 2009 Quaternary Geology and Geomorphology; Geological Publishing House (in Chinese).

Wang S and Ha S 2009 Advances in the study of geomorphology and process of wind erosion landforms; J. Earth Sci. Environ. 31(1) 100-105 (in Chinese with English abstract).

Wang Y T 1990 The research of quaternary basin of Dunhuang in the western Gansu; Gansu Geology 10 39-55 (in Chinese).

Ward A W 1984 Evolution of the yardangs at Rogers Lake, California; The Geological Society of America, pp. 829837.

Xia X C and Zhao Y J 2005 Some latest achievements in research in the environment and evolution of Lop Nur region; NSFC 04 196-200 (in Chinese with English abstract).

Xia X C 2007 The Lop Nor; Science Press, Beijing, pp. 61-65 (in Chinese).

Yao $\mathrm{T}$ D, Thompson L G, Shi Y F, Qin D H, Jiao K Q, Yang Z H, Tian L D and Mosley-Thompson E 1997 Record of climate change during the last glaciations in Guliya ice core; Sci. Chin. (Ser. D) 05 447-452 (in Chinese).

Zhao R S, Zhao Z X, Fan W G, Zhou Z H and Mao J H 2009 Geology of Gansu; Bureau of Geology and Mineral Resources of Gansu Province (in Chinese).

Zheng B X, Zhang L Y and Hu X H 2002 Distribution and characteristics of yardang landform and its formation period, west to Yumenguan, Gansu; J. Desert Res. 22(1) 40-46 (in Chinese with English abstract).

Zheng R Z 2005 Tectonic Uplift and Deformation Mechanism of the Altun Structural System Since the MiddleLate period of Late Pleistocene Time; Institute of Geology, China Earthquake Administration (in Chinese with English abstract). 